\title{
The Influence of Price, Service Quality, and Word Of Mouth on the Purchase Decision of PT Daniel Samudra Abadi's Loading and Unloading Services
}

\author{
Alexandra Marcellina Harindah Siswanto \\ School Of Business and Management, Universitas Ciputra Surabaya \\ amarcellinaharindah@yahoo.co.id \\ https://doi.org/10.37715/rmbe.v1i2.2425
}

\begin{abstract}
PT Daniel Samudra Abadi is a company engaged in stevedoring services. The services provided are specialized in products, such as steel (cold rolled steel sheet, steel sheet in coil, steel plate, prime concast steel slab, etc.), pulp, and general cargo. The purpose of this research is to determine the influence of price, service quality and word of mouth on the purchase decision of stevedoring service. The population in this research are consumers of PT Daniel Samudra Abadi who have used service from 2018-2020 period with 31 companies as a sample. Determination of the sample in this research using saturated samples. This research uses multiple linear regression analysis. The results showed that all independent variables, namely price, service quality and word of mouth have a positive and significant effect on the purchase decision of PT Daniel Samudra Abadi stevedoring service.
\end{abstract}

Keywords—Stevedoring Services, Price, Service Quality, Word Of Mouth, Purchase Decision, Multiple Linear Regression.

\section{Introduction}

Since the entry into force of the ASEAN Economic Community (AEC) in 2015, more and more new companies have been established from various industrial aspects that require imported goods from abroad. This gives rise to many business opportunities to support the import process in Indonesia, such as loading and unloading services, trucking, ship loading expeditions, surveyors, and others. PT Daniel Samudra Abadi is a company engaged in loading and unloading services. This company was founded in August 2013 and is located in Surabaya. The services provided specialize in products such as steel (cold rolled steel sheet, steel sheet in coil, steel plate, prime concast steel slab, etc.), pulp, and general cargo. In addition to offering loading and unloading services, PT Daniel Samudra Abadi also has other complementary services, such as shipping freight forwarders (EMKL), trucking, and surveyors. The number of similar business competition that is increasingly competitive, makes the author interested in analyzing the effect of service quality, price, and word of mouth on the purchase decision of PT Daniel Samudra Abadi's loading and unloading services in order to increase the company's sales turnover.

The benefits of this research are expected to be taken into consideration and can provide information about several factors that influence the decision to purchase loading and unloading services at PT Daniel Samudra Abadi. So that the company can rearrange the appropriate strategy to increase the sales turnover of PT Daniel Samudra Abadi. The results of this study are also expected to be an informative source and also reference material for other researchers who use the same topic.

\section{Literature Review}

\subsection{Previous Research}

Research conducted by Dea and Anti (2019) with the title "Analysis of the Effect of Price, Company Image and Service Quality on Customer Satisfaction in Cargo Delivery Services at PT. Serasi Shipping Indonesia Semarang Branch" aims to determine whether or not the influence of price factors, company image and service quality on customer satisfaction of PT. Serasi Shipping Indonesia Semarang Branch. The result of this research is that there is a positive and significant influence individually or partially between price, company image, and service quality on customer satisfaction. Research conducted by Dea and Anti (2019) is used by researchers as a reference because it has the same variables, namely price and service quality. 
Research conducted by Kaura, et al. (2015) with the title "Service Quality, Service Convenience, Price and Fairness, Customer Loyalty, and The Mediating Role of Customer Satisfaction" aims to examine the effect of service quality, perceived price and fairness and service convenience on customer satisfaction and customer loyalty for the sector. Indian retail banking. The results of this study indicate that service quality, price perception, and fairness and service convenience have a positive impact on customer satisfaction and customer loyalty. Research conducted by Kaura, et al. (2015) is used by researchers as a reference because it has the same variables, namely service quality and price.

Research conducted by Farli and Tielung (2015) with the title " Pengaruh citra merek, kualitas layanan dan lokasi terhadap keputusan konsumen menggunakan jasa Salon Headquarters Manado Town Square " aims to determine the effect of brand image, service quality, and location both simultaneously and partially on consumer decisions in using salon services. The results of this study indicate that simultaneously brand image, service quality and location affect consumer decisions. Partially brand image and service quality affect consumer decisions. Research conducted by Farli and Tielung (2015) is used by researchers as a reference because it has the same variables, namely service quality and purchasing decisions.

\subsection{Theoretical basis}

\subsubsection{Price}

According to Setyo (2017, p. 758) price is the amount of value or money that is exchanged by consumers for a product or service that has benefits for consumers when having or using it. According to Fadil and Priyo (2015, p. 140) "Price is the amount paid by consumers to get products or services sold by your business". Furthermore, according to Sutanto (2010) the price of a product is often used as a reference by consumers in assessing the quality of a product. According to Kotler and Keller (2016, p. 78)there are four price indicators:

1. Price affordability

2. Price match with quality

3. Price match with benefits

4. Price competitiveness

According to Tjiptono (2015, p. 95) price has an important role in influencing purchasing decisions:

1. The allocation role of price: The function of price to help buyers decide how to obtain the highest expected benefit or utility based on their purchasing power. Prices also help buyers to allocate their purchasing power to various types of goods and services.

2. Informational role of price: Another function of price is to educate buyers about product factors, such as quality. This is useful for buyers in the face of difficulty in assessing the product's factors or benefits objectively.

\subsubsection{Service Quality}

According to Kasmir (2017, p. 47) service is an act or deed carried out by a person or organization in order to provide satisfaction to customers or fellow employees. According to Jimanto (2014, p. 3) service quality is the fulfillment of customer needs and desires and the accuracy of delivery to balance the expectations of its customers. Thus, good or bad the quality of services provided by the company depends on the company's ability as a service provider to consistently meet customer expectations (Sulayman et al., 2013, p. 3). According to Hidayat and Firdaus (2014, p. 239) there are five indicators that determine service quality, namely as follows:

1. Tangibles : The physical appearance of the company such as modern buildings and equipment, facilities that are visually appealing, employees who look neat and professional, and other supporting facilities related to services. Tangible indicators are generally used to build the company's image in the eyes of customers.

2. Reliability : The company's ability to provide services that are accurate and as promised. Reliable in handling customer service problems, delivering correct services from the start, providing services at the time promised, maintaining and storing information accurately. Reliability indicators are very vital for customers, so customers are willing to incur additional costs so that the company can provide services as promised.

3. Responsiveness : The company's willingness to always provide accurate and precise information and services to customers. Prioritizing service to customers, helping customers, and always ready to respond to 
any customer requests. The responsiveness indicator emphasizes the company's speed in responding to every request and problems faced by customers.

4. Assurance : A guarantee provided by the company in order to foster a sense of customer trust, so as to make customers feel safe in transactions. Friendly service employees who have the knowledge and skills to handle any customer questions or problems. Insurance indicators are very important for companies engaged in services with high risk.

5. Empathy : The company understands the problems faced by its customers, gives individual attention, treats customers with care, understands and prioritizes customer interests, as well as proper working hours in serving customers. Empathy indicator is the company's effort to convince customers that they are unique and special.

\subsubsection{Word of mouth}

According to Kotler and Keller (2012, p. 254) word of mouth is a communication carried out by the public orally, in writing or using electronic devices related to excellence or experience in using a product or service. According to Hasan (2013, p. 133) word of mouth is a marketing strategy that is believed to be more quickly trusted by customers and has a fairly important role in the context of consumer buying behavior. Furthermore, according to Sernovitz (2015) there are 3 things that can be done so that other people talk about our products or services in word of mouth marketing, namely:

a) Be Interesting : Creating a product or service that is interesting and has a difference. Some companies create similar products or services, but have different characteristics to make them interesting to talk about.

b) Make People Happy : Creating an amazing product or service, excellent service, fix some problems that occur, and make sure a job that the company does can make consumers talk about the product to their friends. Word of mouth will easily occur if the company can make consumers happy with the products or services offered.

c) Earn Trust and Respect : Companies must earn the trust and respect of customers. Without trust, people will be reluctant to recommend products or services that the company provides because this will harm their self-esteem image.

\subsubsection{Buying decision}

According to Farli and Tielung (2015, p. 1109) purchasing decisions are a solving process that combines knowledge to evaluate two or more alternatives and choose one of them before making a decision to buy a product. Furthermore, according to Kotler and Keller (2012, p. 166) the purchase decision consists of five stages, namely problem recognition, information search, evaluation of alternatives, purchase decisions, post-purchase behavior. Purchasing Decision Indicators according to Kotler and Keller (2012, p. 175):

1. Stability in a product: The quality of a good product or service can build a sense of trust in consumers so that it can support consumer satisfaction.

2. Habits in buying a product: Consumer behavior in purchasing the same product repeatedly and continuously.

3. Providing recommendations to others: Providing reliable information to one or more individuals, such as suggesting, inviting to join, and suggesting a form of command.

4. Repurchase: the purchase of a product, goods or services by one or more individuals, and decide to buy again repeatedly, it is called repeat purchase. 


\section{Research Methods}

\subsection{Analysis Model}

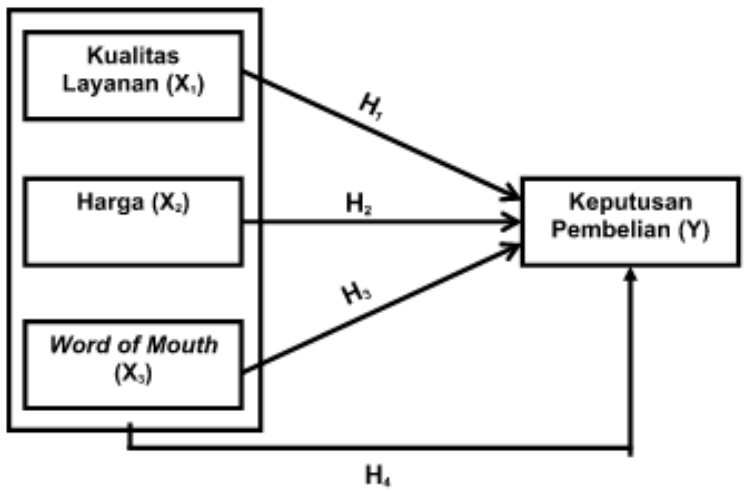

Figure 3.1. Analysis Model

Sources : Data processed, 2021

\subsection{Research Hypothesis}

- $\mathrm{H}_{1}$ : Service quality has a significant effect on purchasing decisions for loading and unloading services at PT Daniel Samudra Abadi.

- $\mathrm{H}_{2}$ : Price has a significant effect on the decision to purchase loading and unloading services at PT Daniel Samudra Abadi.

- $\mathrm{H}_{3}$ : Word of mouth has a significant effect on purchasing decisions for loading and unloading services at PT Daniel Samudra Abadi.

- $\mathrm{H}_{4}$ : Service quality, price and word of mouth simultaneously have a significant effect on purchasing decisions for loading and unloading services at PT Daniel Samudra Abadi.

\subsection{Research Approach}

The type of this research is quantitative research. The method used in this research is descriptive quantitative. The population used is the entire customer who has used the loading and unloading services of PT Daniel Samudra Abadi for the 2018-2020 period. According to Sugiyono $(2018$, p. 81) the sample is part of a characteristic that comes from the population. The number of samples from this study were 31 companies. The sampling technique used in this study is a saturated sampling technique. Furthermore, according to Sugiyono (2018, p. 83) saturated sampling is a sampling technique when all members of the population are used as samples. Primary data in this study were obtained through questionnaires distributed to 31 customers of PT Daniel Samudra Abadi. Secondary data sources can be obtained by reading, studying, and understanding data from literature, books, and company documents. Secondary data in this study are previous research, literature, and internal data of PT Daniel Samudra Abadi. Methods of data collection using a questionnaire method and using a Likert scale. The questionnaire is a data collection technique that is carried out by giving several questions as well as written statements to the respondents to be answered (Sugiyono, 2017, p. 199). Furthermore, according to Sugiyono (2017, p. 135) the Likert scale has five categories, namely:

1. Strongly agree $(\mathrm{SS})=$ score 5

2. Agree $(\mathrm{S})=$ score 4

3. Disagree $(\mathrm{KS})=$ score 3

4. Disagree $(\mathrm{TS})=$ score 2

5. Strongly disagree $(\mathrm{STS})=$ score 1

\subsection{Data analysis method}

3.4.1. Validity and Reliability Test

Validity test is used to measure whether or not a questionnaire is valid (Sugiyono, 2016). Pearson Correlation is used to determine the validity of the questionnaire questions by seeing whether the questions in the questionnaire meet the requirements by showing a value of sig $<0.05$ then the questions in the questionnaire are said to be valid. Reliability test is data to measure a questionnaire which is an indicator of a variable. According to Sujarweni (2016) the level of reliability of a variable can be carried out simultaneously on all questions. If the 
Cronbach Alpha value > 0.6 and Cronbach Alpha is greater than Cronbach Alpha if Deleted (Sunyoto, 2012, p. 45) then the variable is reliable.

\subsubsection{Multiple Linear Regression Analysis}

The data analysis model used multiple linear regression analysis. The regression equation in this study is:

$$
Y=\alpha+\beta_{1} X_{1}+\beta_{2} X_{2}+\beta_{3} X_{3}+\varepsilon
$$

Description:

Y

$\alpha$

$\beta_{1}, \beta_{2}, \beta_{3}$

$\mathrm{X}_{1}$

$\mathrm{X}_{2}$

$\mathrm{X}_{3}$

$\varepsilon$

\subsubsection{Hypothesis testing}

a) F Test (Simultaneous Test)

The $\mathrm{F}$ test is used to determine whether the independent variables together have a significant effect on the dependent variable. The decision-making criteria are:

a. If the significant value is $<0.05$, then the independent variables have a significant effect on the dependent variable.

b. If the significant value is $>0.05$, then the independent variables have no significant effect on the dependent variable.

b) $\mathrm{T}$ test (Partial Test)

The $t$ test was used to determine whether the independent variable individually or partially had a significant effect on the dependent variable. The decision-making criteria are:

a. If significant $>0.05$, then the independent variable does not have a significant influence individually on the dependent variable.

b. If significant 0.05 , then the independent variable has a significant influence individually on the dependent variable.

c) Coefficient of Determination Test $\left(\mathrm{R}^{2}\right)$

The coefficient of determination test $\left(\mathrm{R}^{2}\right)$ is used to find out how far the closeness of the relationship between the independent variable and the dependent variable is. The value of the coefficient of determination is between 0 and 1. If the value of $\mathrm{R}^{2}$ is getting smaller, then the ability of the independent variables to explain the dependent variable is very limited. Furthermore, if the value of $\mathrm{R}^{2}$ is close to 1 , the independent variables provide almost all the information needed to predict the dependent variable.

\subsubsection{Classic assumption test}

a) Heteroscedasticity Test

Heteroscedasticity test is used to determine whether or not there is a deviation from the classical assumption of heteroscedasticity, namely the existence of an inequality of variance from the residuals for all observations in the regression model. The prerequisite that must be met in the regression model is the absence of heteroscedasticity symptoms. This study uses the Glejser test which is carried out by regressing between the independent variables and the absolute residual value. If the significance value between the independent variable and the absolute residual is more than 0.05 , then there is no heteroscedasticity problem.

b) Multicollinearity Test

To detect the presence or absence of multicollinearity in the regression can be seen from:

1. Tolerance value $>0.10$ and

2. Variance inflation factor (VIF), if the VIF value is $<10$, then there is no multicollinearity (Sujarweni, 2016:185).

c) Normality test

Using the Kolmogorov-Smirnov test. Decision making basis:

1. If the significance value 0.05 then the residuals are normally distributed. 
2. If the significance value is $<0.05$ then the residuals are not normally distributed.

d) Autocorrelation Test

Autocorrelation arises with consecutive observations over time and relates to one another. Autocorrelation occurs in the sample with time series data. The autocorrelation test uses the Durbin Watson (DW) value, if the value of du < value of Durbin Watson < 4-du then there is no autocorrelation (V. W. Sujarweni, 2016, p. 186).

e) Linearity Test

The linearity test aims to determine whether two variables have a linear relationship or not significantly. This test is usually used as a prerequisite in correlation analysis or linear regression. Testing on SPSS using Deviation from Linearity with a significance level of 0.05 . Two variables are said to have a linear relationship if the significance (Deviation from Linearity) is more than 0.05 .

\section{Result and Discussion}

\subsection{Respondents Descriptive Analysis}

Respondents in this study were all customers who had used the loading and unloading services of PT Daniel Samudra Abadi for the 2018-2020 period as many as 31 respondents. gender characteristics of the respondents were mostly male as many as 26 respondents $(83.9 \%)$, while female respondents were 5 respondents $(16.1 \%)$. the age characteristics of the respondents mostly came from the age range of 41-45 years as many as 10 respondents $(32.3 \%)$. In the second place, there are 2 age groups, namely 36-40 years old with 7 respondents (22.6\%) and 46-50 years old $(22.6 \%)$ with the same number of respondents. Followed by the age group 31-35 years (19.4\%) and 25-30 years (3.2\%). Most of the respondents work as employees (74.2\%) with a total of 23 respondents. While the rest are included in the other category $(25.8 \%)$ with a total of 8 respondents.

\subsection{Description of Research Variables}

The description of respondents' answers is done by describing the distribution of the questionnaire items from the service quality variable $\left(\mathrm{X}_{1}\right)$, price $\left(\mathrm{X}_{2}\right)$, word of mouth $\left(\mathrm{X}_{3}\right)$, and purchasing decision variables $(\mathrm{Y})$.

4.2.1. Quality of Service $\left(X_{1}\right)$

Table 4.1. Descriptive Statistics Service Quality Variable $\left(X_{1}\right)$

\begin{tabular}{|l|r|r|r|r|r|r|r|r|}
\hline & \multicolumn{1}{|c|}{$\mathrm{N}$} & \multicolumn{1}{c|}{ Range } & Minimum & Maximum & \multicolumn{1}{c|}{ Sum } & \multicolumn{2}{|c|}{ Mean } & Std. Deviation \\
\cline { 2 - 8 } & & & & & & & \multicolumn{1}{c|}{ Std. } & \\
& Statistic & Statistic & Statistic & Statistic & Statistic & Statistic & Error & \multicolumn{1}{c|}{ Statistic } \\
\hline X1.1 & 31 & 3 & 2 & 5 & 126 & 4.06 & .146 & .814 \\
X1.2 & 31 & 3 & 2 & 5 & 121 & 3.90 & .169 & .944 \\
X1.3 & 31 & 3 & 2 & 5 & 129 & 4.16 & .154 & .860 \\
X1.4 & 31 & 2 & 3 & 5 & 126 & 4.06 & .113 & .629 \\
X1.5 & 31 & 3 & 2 & 5 & 128 & 4.13 & .178 & .991 \\
Valid N & 31 & & & & & & & \\
(listwise) & & & & & & & & \\
\hline
\end{tabular}

Source: Data processed by researchers

In the table above, the highest standard deviation is found in the fifth statement of 0.991 , which indicates that the respondents' answers are more varied or heterogeneous, where respondents have different understandings of the fifth statement compared to other statements. While the lowest standard deviation is found in the fourth statement of 0.629 , which indicates that the respondents' answers to this statement are consistent or homogeneous which means that respondents have the same understanding of the statement compared to other statements. 


\subsection{2. $\quad$ Price $\left(X_{2}\right)$}

Table 4.2. Descriptive Statistics Price Variable $\left(\mathrm{X}_{2}\right)$

\begin{tabular}{|l|r|r|r|r|r|r|r|r|}
\hline & \multicolumn{1}{|c|}{$\mathrm{N}$} & Range & Minimum & Maximum & Sum & \multicolumn{2}{|c|}{ Mean } & Std. Deviation \\
\cline { 2 - 9 } & Statistic & Statistic & Statistic & Statistic & Statistic & Statistic & Std. Error & \multicolumn{1}{c|}{ Statistic } \\
\hline X2.1 & 31 & 4 & 1 & 5 & 110 & 3.55 & .190 & 1.060 \\
X2.2 & 31 & 3 & 2 & 5 & 117 & 3.77 & .165 & .920 \\
X2.3 & 31 & 3 & 2 & 5 & 124 & 4.00 & .167 & .931 \\
X2.4 & 31 & 4 & 1 & 5 & 121 & 3.90 & .204 & 1.136 \\
Valid N (listwise) & 31 & & & & & & & \\
\hline
\end{tabular}

Source: Data processed by researchers

In the table above, the highest standard deviation is found in the fourth statement of 1.136, which indicates that the respondents' answers are more varied or heterogeneous, where respondents have different understandings of the fourth statement compared to other statements. While the lowest standard deviation is in the second statement of 0.920, which indicates that the respondents' answers to this statement are consistent or homogeneous which means that respondents have the same understanding of the statement compared to other statements.

\subsubsection{Word Of Mouth $\left(X_{3}\right)$}

Table 4.3. Descriptive Statistics Variable Word Of Mouth $\left(\mathrm{X}_{3}\right)$

\begin{tabular}{|c|c|c|c|c|c|c|c|c|}
\hline & $\mathrm{N}$ & Range & Minimum & Maximum & Sum & \multicolumn{2}{|c|}{ Mean } & $\begin{array}{c}\text { Std. } \\
\text { Deviation }\end{array}$ \\
\hline & Statistic & $\begin{array}{l}\text { Statisti } \\
\text { c }\end{array}$ & Statistic & Statistic & Statistic & Statistic & $\begin{array}{l}\text { Std. } \\
\text { Error }\end{array}$ & Statistic \\
\hline $\mathrm{X} 3.1$ & 31 & 2 & 3 & 5 & 143 & 4.61 & .100 & .558 \\
\hline X3.2 & 31 & 2 & 3 & 5 & 134 & 4.32 & .097 & .541 \\
\hline X3.3 & 31 & 2 & 3 & 5 & 133 & 4.29 & .148 & .824 \\
\hline Valid N (listwise) & 31 & & & & & & & \\
\hline
\end{tabular}

Source: Data processed by researchers

In the table above, the highest standard deviation is found in the third statement of 0.82 , which indicates that the respondents' answers are more varied or heterogeneous, where respondents have different understandings of the fourth statement compared to other statements. While the lowest standard deviation is found in the second statement of 0.541 , which indicates that the respondent's answer to this statement is consistent or homogeneous which means that the respondent has the same understanding of the statement compared to other statements.

\subsubsection{Purchase Decision (Y)}

Table 4.4. Descriptive Statistics Purchase Decision Variable (Y)

\begin{tabular}{|l|r|r|r|r|r|r|r|r|}
\hline \multirow{2}{*}{} & \multicolumn{1}{|c|}{$\mathrm{N}$} & Range & Minimum & Maximum & Sum & \multicolumn{2}{|c|}{ Mean } & Std. Deviation \\
\cline { 2 - 8 } & & & & & \multicolumn{1}{c|}{ Statis } \\
tic & Statistic & Std. Error & \multicolumn{1}{c|}{ Statistic } \\
\hline Y1 & Statistic & Statistic & Statistic & Statistic & 5 & .102 & .568 \\
Y2 & 31 & 2 & 3 & 5 & 141 & 4.55 & .091 & .506 \\
Y3 & 31 & 1 & 4 & 5 & 141 & 4.55 & .091 & .508 \\
Y4 & 31 & 1 & 4 & 5 & 139 & 4.48 & .099 & .551 \\
Y5 & 31 & 2 & 3 & 5 & 144 & 4.65 & .099 & .477 \\
Valid N (listwise) & 31 & 2 & 3 & 5 & 149 & 4.81 & .086 & \\
\hline
\end{tabular}

Source: Data processed by researchers

In the table above, the highest standard deviation is found in the first statement of 0.568 , which indicates that respondents' answers are more varied or heterogeneous, where respondents have different understandings of the fourth statement compared to other statements. While the lowest standard deviation is found in the second statement of 0.477, which indicates that the respondents' answers to this statement are consistent or homogeneous which means that respondents have the same understanding of the statement compared to other statements.

\subsection{Validity and Reliability Test}

\subsubsection{Validity test}

In this validity test, the researcher uses the Pearson Correlation, which is to test the questionnaire statements by seeing whether the statements in the questionnaire meet the requirements by showing a value of sig $<0.05$, then the statement in the questionnaire is declared valid. The validity test in this study used $n=30$, with the criteria for 
the characteristics of the respondents being the same as those to be tested. From the results of data processing through SPSS, it is known that the validity values for each questionnaire item are as follows:

Table 4.5. Free Variable Validity Test

\begin{tabular}{|c|c|c|c|c|}
\hline Variable & Questionnaire Items & $\begin{array}{c}\text { Pearson } \\
\text { Correlation }\end{array}$ & Sig & Description \\
\hline \multirow{5}{*}{$\begin{array}{l}\text { Quality of Service } \\
\qquad\left(X_{1}\right)\end{array}$} & PT Daniel Samudra Abadi has adequate and modern company facilities & 0.668 & 0.000 & Valid \\
\hline & $\begin{array}{l}\text { PT Daniel Samudra Abadi provides fast loading and unloading services as } \\
\text { promised }\end{array}$ & 0.719 & 0.000 & Valid \\
\hline & PT Daniel Samudra Abadi is responsive to every problem faced by customers & 0.662 & 0.000 & Valid \\
\hline & $\begin{array}{l}\text { PT Daniel Samudra Abadi provides guarantee insurance during the operational } \\
\text { process }\end{array}$ & 0.690 & 0.000 & Valid \\
\hline & PT Daniel Samudra Abadi maintains good relationship with customers & 0.636 & 0.000 & Valid \\
\hline \multirow{4}{*}{ Price $\left(\mathbf{X}_{2}\right)$} & $\begin{array}{l}\text { Affordable prices for loading and unloading services are a consideration for using } \\
\text { the services of PT Daniel Samudra Abadi }\end{array}$ & 0.862 & 0.000 & Valid \\
\hline & $\begin{array}{l}\text { The price of the service is in accordance with the quality of loading and unloading } \\
\text { services offered by PT Daniel Samudra Abadi }\end{array}$ & 0.875 & 0.000 & Valid \\
\hline & $\begin{array}{l}\text { The service price is in accordance with the benefits of loading and unloading } \\
\text { services offered by PT Daniel Samudra Abadi }\end{array}$ & 0.927 & 0.000 & Valid \\
\hline & The price of services offered by PT Daniel Samudra Abadi is quite competitive & 0.927 & 0.000 & Valid \\
\hline \multirow{3}{*}{$\begin{array}{c}\text { Word Of } \\
\text { Mouth }\left(\mathrm{X}_{3}\right)\end{array}$} & $\begin{array}{l}\text { I have heard a lot of positive things about the quality of PT Daniel Samudra } \\
\text { Abadi's loading and unloading services from other people }\end{array}$ & 0.943 & 0.000 & Valid \\
\hline & $\begin{array}{l}\text { I got a recommendation for PT Daniel Samudra Abadi's loading and unloading } \\
\text { services from other people }\end{array}$ & 0.727 & 0.000 & Valid \\
\hline & $\begin{array}{l}\text { I got encouragement from my relations to purchase the loading and unloading } \\
\text { services of PT Daniel Samudra Abadi }\end{array}$ & 0.869 & 0.000 & Valid \\
\hline
\end{tabular}

\section{Source: Data processed by researchers}

In Table 4.5. it can be concluded that the validity test on the independent variable questionnaire items, namely service quality $\left(\mathrm{X}_{1}\right)$, price $\left(\mathrm{X}_{2}\right)$, and word of mouth $\left(\mathrm{X}_{3}\right)$ have a correlation and a significance level of less than 0.05 so that the statement on the questionnaire is stated valid.

Table 4.6. Bound Variable Validity Test

\begin{tabular}{|c|c|c|c|c|}
\hline Variable & Questionnaire Items & $\begin{array}{c}\text { Pearson } \\
\text { Correlation }\end{array}$ & Sig & Description \\
\hline \multirow{5}{*}{$\begin{array}{c}\text { Purchase } \\
\text { Decision (Y) }\end{array}$} & $\begin{array}{l}\text { I have a need that can be met by loading and unloading services PT } \\
\text { Daniel Samudra Abadi }\end{array}$ & 0.671 & 0.000 & Valid \\
\hline & $\begin{array}{l}\text { I received information about PT Daniel Samudra Abadi's loading and } \\
\text { unloading services before making a purchase }\end{array}$ & 0.608 & 0.000 & Valid \\
\hline & $\begin{array}{l}\text { I have made a comparison between PT Daniel Samudra Abadi's } \\
\text { loading and unloading services with other loading and unloading } \\
\text { services before making a purchase }\end{array}$ & 0.753 & 0.000 & Valid \\
\hline & $\begin{array}{l}\text { I decided to buy loading and unloading services from PT Daniel } \\
\text { Samudra Abadi with good service quality }\end{array}$ & 0.726 & 0.000 & Valid \\
\hline & $\begin{array}{l}\text { I am satisfied with the loading and unloading services of PT Daniel } \\
\text { Samudra Abadi }\end{array}$ & 0.763 & 0.000 & Valid \\
\hline
\end{tabular}

\section{Source: Data processed by researchers}

In table 4.6. it can be concluded that the validity test on the dependent variable questionnaire items, namely the purchase decision $(\mathrm{Y})$ has a correlation and a significance level of less than 0.05 so that the statement on the questionnaire is declared valid.

\subsubsection{Reliability Test}

The items on the questionnaire can be declared reliable if the Cronbach Alpha value > 0.6. The reliability test in this study used $n=30$, with the criteria for the characteristics of the respondents being the same as those to be tested.

Table 4.7. Reliability Test

\begin{tabular}{|c|c|c|c|c|}
\hline Variable & Indicator & $\begin{array}{c}\text { Cronbach's } \\
\text { Alpha if Deleted }\end{array}$ & $\begin{array}{c}\text { Cronbach's } \\
\text { Alpha }\end{array}$ & Description \\
\hline \multirow{3}{*}{$\begin{array}{c}\text { Quality of } \\
\text { Service (X1) }\end{array}$} & $\begin{array}{l}\text { PT Daniel Samudra Abadi has adequate and modern } \\
\text { company facilities }\end{array}$ & 0.631 & \multirow{3}{*}{0.688} & Reliable \\
\hline & $\begin{array}{l}\text { PT Daniel Samudra Abadi provides fast loading and } \\
\text { unloading services as promised }\end{array}$ & 0.617 & & Reliable \\
\hline & $\begin{array}{l}\text { PT Daniel Samudra Abadi is responsive to every problem } \\
\text { faced by customers }\end{array}$ & 0.642 & & Reliable \\
\hline
\end{tabular}




\begin{tabular}{|c|c|c|c|c|}
\hline & $\begin{array}{l}\text { PT Daniel Samudra Abadi provides guarantee insurance } \\
\text { during the operational process }\end{array}$ & 0.614 & & Reliable \\
\hline & $\begin{array}{l}\text { PT Daniel Samudra Abadi maintains good relationship with } \\
\text { customers }\end{array}$ & 0.688 & & Reliable \\
\hline \multirow{4}{*}{ Price (X2) } & $\begin{array}{l}\text { Affordable prices for loading and unloading services are a } \\
\text { consideration for using the services of PT Daniel Samudra } \\
\text { Abadi }\end{array}$ & 0.914 & \multirow{4}{*}{0.917} & Reliable \\
\hline & $\begin{array}{l}\text { The price of the service is in accordance with the quality of } \\
\text { loading and unloading services offered by PT Daniel } \\
\text { Samudra Abadi }\end{array}$ & 0.901 & & Reliable \\
\hline & $\begin{array}{l}\text { The service price is in accordance with the benefits of } \\
\text { loading and unloading services offered by PT Daniel } \\
\text { Samudra Abadi }\end{array}$ & 0.874 & & Reliable \\
\hline & $\begin{array}{l}\text { The price of services offered by PT Daniel Samudra Abadi is } \\
\text { quite competitive }\end{array}$ & 0.879 & & Reliable \\
\hline \multirow{3}{*}{$\begin{array}{l}\text { Word Of } \\
\text { Mouth (X3) }\end{array}$} & $\begin{array}{l}\text { I have heard a lot of positive things about the quality of PT } \\
\text { Daniel Samudra Abadi's loading and unloading services from } \\
\text { other people }\end{array}$ & 0.466 & \multirow{3}{*}{0.782} & Reliable \\
\hline & $\begin{array}{l}\text { I got a recommendation for PT Daniel Samudra Abadi's } \\
\text { loading and unloading services from other people }\end{array}$ & 0.825 & & Reliable \\
\hline & $\begin{array}{l}\text { I got encouragement from my relations to purchase the } \\
\text { loading and unloading services of PT Daniel Samudra Abadi }\end{array}$ & 0.804 & & Reliable \\
\hline \multirow{5}{*}{$\begin{array}{c}\text { Purchase } \\
\text { Decision (Y) }\end{array}$} & $\begin{array}{l}\text { I have a need that can be met by loading and unloading } \\
\text { services PT Daniel Samudra Abadi }\end{array}$ & 0.726 & \multirow{5}{*}{0.743} & Reliable \\
\hline & $\begin{array}{l}\text { I received information about PT Daniel Samudra Abadi's } \\
\text { loading and unloading services before making a purchase }\end{array}$ & 0.739 & & Reliable \\
\hline & $\begin{array}{l}\text { I have made a comparison between PT Daniel Samudra } \\
\text { Abadi's loading and unloading services with other loading } \\
\text { and unloading services before making a purchase }\end{array}$ & 0.668 & & Reliable \\
\hline & $\begin{array}{l}\text { I decided to buy loading and unloading services from PT } \\
\text { Daniel Samudra Abadi with good service quality }\end{array}$ & 0.69 & & Reliable \\
\hline & $\begin{array}{l}\text { I am satisfied with the loading and unloading services of PT } \\
\text { Daniel Samudra Abadi }\end{array}$ & 0.661 & & Reliable \\
\hline
\end{tabular}

The table above shows that the results of the reliability test on the research variables, namely service quality $\left(\mathrm{X}_{1}\right)$, price $\left(\mathrm{X}_{2}\right)$, word of mouth $\left(\mathrm{X}_{3}\right)$, and purchasing decisions $(\mathrm{Y})$ have a Cronbach Alpha value greater than 0.06 so it can be concluded that all questionnaire items in this study are reliable.

\subsection{Multiple Linear Regression Analysis}

Multiple linear regression analysis was used to determine the effect between the independent variable and the dependent variable. The independent variables in this study are service quality $\left(\mathrm{X}_{1}\right)$, price $\left(\mathrm{X}_{2}\right)$, and word of mouth $\left(\mathrm{X}_{3}\right)$. Furthermore, the dependent variable in this study is the purchase decision (Y). Based on the results of data processing, the results of multiple linear regression are obtained as follows:

Table 4.8. Multiple Linear Regression

\begin{tabular}{|l|c|r|r|r|}
\hline & B & Std. Error & t & Sig. \\
\hline Constant & 9,016 & 1,510 & 5,973 & 0.000 \\
\hline Quality of Service $\left(\mathbf{X}_{1}\right)$ & 0.172 & 0.063 & 2,710 & 0.012 \\
\hline Price $\left(\mathbf{X}_{2}\right)$ & 0.229 & 0.048 & 4,743 & 0.000 \\
\hline Word of mouth $\left(\mathbf{x}_{3}\right)$ & 0.532 & 0.112 & 4,750 & 0.0 \\
\hline
\end{tabular}

Source: Data processed by researchers

Based on Table 4.8, the regression equation in this study is:

$$
\mathrm{Y}=9,016+0,172 \mathrm{X}_{1}+0,229 \mathrm{X}_{2}+0,532 \mathrm{X}_{3}
$$

The linear regression equation shows that the service quality variable has a positive coefficient value of 0.172. The value of a positive coefficient indicates unidirectional relationship between the variables of service quality $\left(\mathrm{X}_{1}\right)$ with purchasing decisions $(\mathrm{Y})$, then if the quality of service PT Daniel Samudra Abadi, the better the buying decision will increase with conditions $\left(\mathrm{X}_{2}\right)$ and word of mouth $\left(\mathrm{X}_{3}\right)$ has a fixed value. Furthermore, this is also indicated by the price variable $\left(\mathrm{X}_{2}\right)$ which has a positive coefficient value of 0.229 . A positive coefficient value indicates a unidirectional relationship between the price variable $\left(\mathrm{X}_{2}\right)$ and the purchase decision $(\mathrm{Y})$, so if the price of PT Daniel Samudra Abadi's services is appropriate, the purchasing decision will increase with the provision of service quality $\left(X_{1}\right)$ and word of mouth $\left(X_{3}\right)$ has a fixed value. The word of mouth variable $\left(X_{3}\right)$ also has a positive coefficient value of 0.532 . The value of a positive coefficient indicates unidirectional relationship between the variables word of mouth $\left(\mathrm{X}_{3}\right)$ with the purchase decision $(\mathrm{Y})$, then if the word of mouth PT Daniel Samudra Abadi 
goes well then purchasing decisions will be improved by the provision of quality of service $\left(\mathrm{X}_{1}\right)$ and the price $\left(\mathrm{X}_{2}\right)$ is fixed.

\subsection{Classic assumption test}

\subsubsection{Normality test}

Table 4.9. Normality test

\begin{tabular}{|c|c|c|}
\hline \multicolumn{3}{|c|}{ One-Sample Kolmogorov-Smirnov Test } \\
\hline & & $\begin{array}{c}\text { Unstandardized } \\
\text { Residual }\end{array}$ \\
\hline \multicolumn{2}{|l|}{$\mathrm{N}$} & 31 \\
\hline \multirow{2}{*}{$\begin{array}{l}\text { Normal } \\
\text { Parameters, }\end{array}$} & Mean & .0000000 \\
\hline & Std. Deviation & .85083537 \\
\hline \multirow{3}{*}{$\begin{array}{l}\text { Most Extreme } \\
\text { Differences }\end{array}$} & Absolute & .109 \\
\hline & Positive & .109 \\
\hline & Negative & -.073 \\
\hline \multicolumn{2}{|c|}{ Test Statistic } & .109 \\
\hline \multicolumn{2}{|c|}{ Asymp. Sig. (2-tailed) } & $.200^{\mathrm{c}, \mathrm{d}}$ \\
\hline \multicolumn{3}{|c|}{ a. Test distribution is Normal. } \\
\hline \multicolumn{3}{|c|}{ b. Calculated from data. } \\
\hline \multicolumn{3}{|c|}{ c. Lilliefors Significance Correction. } \\
\hline \multicolumn{3}{|c|}{$\mathrm{d}$. This is a lower bound of the true significance. } \\
\hline
\end{tabular}

\section{Source: Data processed by researchers}

Table 4.9 shows that the Kolmogorov-Smirnov test results show a significance value of 0.200 , where the value is greater than 0.05 , it can be concluded that the residual distribution meets the assumptions of the normality test.

\subsubsection{Linearity Test}

Table 4.10. Service Quality Linearity Test $\left(\mathrm{X}_{1}\right)$ on Purchase Decision $(\mathrm{Y})$

\begin{tabular}{|c|c|c|c|c|c|c|c|}
\hline \multicolumn{8}{|c|}{ ANOVA Table } \\
\hline & & & $\begin{array}{l}\text { Sum of } \\
\text { Squares }\end{array}$ & df & $\begin{array}{l}\text { Mean } \\
\text { Square }\end{array}$ & $\mathrm{F}$ & Sig. \\
\hline \multirow{5}{*}{$\begin{array}{l}\text { YTotal * } \\
\text { X1Total }\end{array}$} & \multirow[t]{3}{*}{ Between Groups } & (Combined) & 49.634 & 9 & 5.515 & 2.172 & .069 \\
\hline & & Linearity & 36.504 & 1 & 36.504 & 14.373 & .001 \\
\hline & & Deviation from Linearity & 13.131 & 8 & 1.641 & .646 & .731 \\
\hline & \multicolumn{2}{|l|}{ Within Groups } & 53.333 & 21 & 2.540 & & \\
\hline & \multicolumn{2}{|l|}{ Total } & 102.968 & 30 & & & \\
\hline
\end{tabular}

Source: Data processed by researchers

Table 4.10 shows that the value Deviation from Linearity significance 0.731 , where the value is greater than 0.05 , it can be concluded that there is a linear relationship significantly between the variable quality of service $\left(\mathrm{X}_{1}\right)$ dengann purchase decision variable $(\mathrm{Y})$.

Table 4.11 Price Linearity Test $\left(\mathrm{X}_{2}\right)$ on Purchase Decision (Y)

\begin{tabular}{|c|c|c|c|c|c|c|c|}
\hline \multicolumn{8}{|c|}{ ANOVA Table } \\
\hline & & & $\begin{array}{l}\text { Sum of } \\
\text { Squares }\end{array}$ & df & $\begin{array}{l}\text { Mean } \\
\text { Square }\end{array}$ & $\mathrm{F}$ & Sig. \\
\hline \multirow[t]{5}{*}{ YTotal * X2Total } & \multirow[t]{3}{*}{ Between Groups } & (Combined) & 75.468 & 10 & 7.547 & 5.489 & .001 \\
\hline & & Linearity & 45.936 & 1 & 45.936 & 33.408 & .000 \\
\hline & & Deviation from Linearity & 29.531 & 9 & 3.281 & 2.386 & .051 \\
\hline & \multicolumn{2}{|l|}{ Within Groups } & 27.500 & 20 & 1.375 & & \\
\hline & \multicolumn{2}{|l|}{ Total } & 102.968 & 30 & & & \\
\hline
\end{tabular}

Source: Data processed by researchers

Table 4.11 shows that the value Deviation from Linearity significance 0.051 , where the value is greater than 0.05 , it can be concluded that there is a linear relationship significantly between price variables $\left(\mathrm{X}_{2}\right)$ the purchase decision variable $(\mathrm{Y})$.

Table 4.12. Word Of Mouth Linearity Test $\left(\mathrm{X}_{3}\right)$ on Purchase Decision (Y)

\begin{tabular}{|c|c|l|c|c|c|c|c|}
\hline \multicolumn{9}{|c|}{ ANOVA Table } & $\begin{array}{c}\text { Sum of } \\
\text { Squares }\end{array}$ & df & $\begin{array}{c}\text { Mean } \\
\text { Square }\end{array}$ & F & Sig. \\
\hline \multirow{2}{*}{ YTotal * X3Total } & Between Groups & (Combined) & 66.706 & 5 & 13.341 & 9.198 & .000 \\
\cline { 3 - 9 } & & Linearity & 51.211 & 1 & 51.211 & 35.306 & .000 \\
\cline { 2 - 9 } & & Deviation from Linearity & 15.495 & 4 & 3.874 & 2.671 & .056 \\
\cline { 2 - 9 } & Within Groups & 36.262 & 25 & 1.450 & & \\
\hline
\end{tabular}




\begin{tabular}{|l|l|l|l|l|l|l|}
\hline & Total & 102.968 & 30 & & & \\
\hline
\end{tabular}

Source: Data processed by researchers

The above table shows that the value Deviation from Linearity significance 0.056 , where the value is greater than 0.05 , it can be concluded that there is a linear relationship between the variables significantly word of mouth $\left(\mathrm{X}_{3}\right)$ with the purchase decision variable $(\mathrm{Y})$.

\subsubsection{Multicollinearity Test}

Table 4.13. Multicollinearity Test

\begin{tabular}{|c|c|c|c|c|c|c|c|c|}
\hline \multicolumn{9}{|c|}{ Coefficients $^{\mathbf{a}}$} \\
\hline & \multirow{2}{*}{ Model } & \multicolumn{2}{|c|}{$\begin{array}{l}\text { Unstandardized } \\
\text { Coefficients }\end{array}$} & \multirow{2}{*}{$\begin{array}{c}\begin{array}{c}\text { Standardized } \\
\text { Coefficients }\end{array} \\
\text { Beta }\end{array}$} & \multirow[t]{2}{*}{$\mathrm{t}$} & \multirow[t]{2}{*}{ Sig. } & \multicolumn{2}{|c|}{$\begin{array}{c}\text { Collinearity } \\
\text { Statistics }\end{array}$} \\
\hline & & $\mathrm{B}$ & Std. Error & & & & Tolerance & VIF \\
\hline \multirow[t]{4}{*}{1} & (Constant) & 9.016 & 1.510 & & 5.973 & .000 & & \\
\hline & X1Total & .172 & .063 & .268 & 2.710 & .012 & .797 & 1.254 \\
\hline & X2Total & .229 & .048 & .449 & 4.743 & .000 & .871 & 1.148 \\
\hline & X3Total & .532 & .112 & .467 & 4.750 & .000 & .808 & 1.237 \\
\hline
\end{tabular}

Table 4.13 shows that the VIF values for service quality variables $\left(\mathrm{X}_{1}\right)$, price $\left(\mathrm{X}_{2}\right)$, and word of mouth $\left(\mathrm{X}_{3}\right)$ are each smaller than 10. Furthermore, the tolerance value for each independent variable is also greater than 0.10 so it can be concluded that there is no multicollinearity in the regression model of this study.

\subsubsection{Heteroscedasticity Test}

Table 4.14. Heteroscedasticity Test

\begin{tabular}{|c|c|c|c|c|c|c|c|c|}
\hline \multicolumn{9}{|c|}{ Coefficients $^{\mathbf{a}}$} \\
\hline \multirow{2}{*}{\multicolumn{2}{|c|}{ Model }} & \multicolumn{2}{|c|}{$\begin{array}{l}\text { Unstandardized } \\
\text { Coefficients }\end{array}$} & \multirow{2}{*}{$\begin{array}{c}\begin{array}{l}\text { Standardized } \\
\text { Coefficients }\end{array} \\
\text { Beta } \\
\end{array}$} & \multirow[t]{2}{*}{$\mathrm{t}$} & \multirow[t]{2}{*}{ Sig. } & \multicolumn{2}{|c|}{$\begin{array}{l}\text { Collinearity } \\
\text { Statistics }\end{array}$} \\
\hline & & B & Std. Error & & & & Tolerance & VIF \\
\hline \multirow[t]{4}{*}{1} & (Constant) & 1.241 & .892 & & 1.391 & .176 & & \\
\hline & X1Total & -.005 & .037 & -.026 & -.128 & .899 & .797 & 1.254 \\
\hline & X2Total & -.040 & .029 & -.279 & -1.408 & .171 & .871 & 1.148 \\
\hline & X3Total & .010 & .066 & .030 & .146 & .885 & .808 & 1.237 \\
\hline
\end{tabular}

The table above shows that the significance value of service quality variables $\left(\mathrm{X}_{1}\right)$, price $\left(\mathrm{X}_{2}\right)$, and word of mouth $\left(\mathrm{X}_{3}\right)$ are each greater than 0.05 , so it can be concluded that there is no heteroscedasticity in the regression model of this study.

\subsubsection{Autocorrelation Test}

Table 4.15 Autocorrelation Test

\begin{tabular}{|l|c|c|c|c|r|}
\hline \multicolumn{7}{|c|}{ Model Summary $^{\mathbf{b}}$} \\
\hline Model & $\mathrm{R}$ & $\begin{array}{c}\mathrm{R} \\
\text { Square }\end{array}$ & $\begin{array}{c}\text { Adjusted R } \\
\text { Square }\end{array}$ & $\begin{array}{c}\text { Std. Error of } \\
\text { the Estimate }\end{array}$ & $\begin{array}{r}\text { Durbin- } \\
\text { Watson }\end{array}$ \\
\hline 1 & $.888^{\mathrm{a}}$ & .789 & .766 & .897 & 2.198 \\
\hline a. Predictors: (Constant), X3Total, X2Total, X1Total \\
\hline \multicolumn{7}{|l|}{ b. Dependent Variable: YTotal } \\
\hline
\end{tabular}

Source: Data processed by researchers

The table above shows that the Durbin-Watson value shows a value of 2,198. Furthermore, this study uses the amount of data (n) as many as 31 respondents with the number of independent variables as much as 3 , namely the service quality variable $\left(X_{1}\right)$, price $\left(X_{2}\right)$, and word of mouth $\left(X_{3}\right)$. In this study, the researcher used a significance value of $0.05, \mathrm{n}=31, \mathrm{k}=3$ and the resulting $\mathrm{dU}$ value of 1.6500 . Furthermore, the reference range is $\mathrm{dU}=1.6500$ to $(4-\mathrm{dU})=2.3500$. The Durbin-Watson value in this study is between 1.6500 and 2.3500 , so it can be concluded that there is no autocorrelation.

\subsection{Hypothesis testing}

\subsection{1. $\quad$ t test}

At 4:15 table known to influence the quality of service $(\mathrm{X}-1)$ to the purchasing decision $(\mathrm{Y})$ produce $t_{\text {count }} 2,710$ bigger than $t_{\text {table }}$. The significance value of service quality $\left(X_{1}\right)$ is 0.012 which is less than 0.05 , it can be concluded that service quality partially has a significant effect on purchasing decisions for loading and unloading services at PT Daniel Samudra Abadi. Based on this, the hypothesis H1 is accepted. Furthermore, the effect of price $\left(\mathrm{X}_{2}\right)$ on purchase decisions $(\mathrm{Y})$ produced $4,743 \mathrm{t}$ greater than $\mathrm{t}$ table. The price significance value $\left(\mathrm{X}_{2}\right)$ is 0.000 which is less than 0.05 , so it can be concluded that the price partially has a significant effect on the purchase decision of PT Daniel Samudra Abadi's loading and unloading services. Based on these conditions, the hypothesis $\mathrm{H}_{2}$ is accepted. The influence of word of mouth $\left(\mathrm{X}_{3}\right)$ to the purchasing decision $(\mathrm{Y})$ produce $\mathrm{t}_{\text {count }} 4.750$ greater than 
$t_{\text {table }}$. The significance value of word of mouth $\left(X_{3}\right)$ is 0.000 which is less than 0.05 , it can be concluded that word of mouth partially has a significant effect on purchasing decisions for loading and unloading services at PT Daniel Samudra Abadi. Based on these conditions, the hypothesis $\mathrm{H}_{3}$ accepted.

\subsection{2. $\quad$ F test}

Table 4.16. F test

\begin{tabular}{|c|c|c|c|c|c|c|}
\hline \multicolumn{7}{|c|}{ ANOVA $^{\mathbf{a}}$} \\
\hline \multicolumn{2}{|r|}{ Model } & $\begin{array}{l}\text { Sum of } \\
\text { Squares }\end{array}$ & $\mathrm{df}$ & $\begin{array}{l}\text { Mean } \\
\text { Square }\end{array}$ & $\mathrm{F}$ & Sig. \\
\hline \multirow[t]{3}{*}{1} & Regression & 81.250 & 3 & 27.083 & 33.671 & $.000^{\mathrm{b}}$ \\
\hline & Residual & 21.718 & 27 & .804 & & \\
\hline & Total & 102.968 & 30 & & & \\
\hline \multicolumn{7}{|c|}{ a. Dependent Variable: YTotal } \\
\hline \multicolumn{7}{|c|}{ b. Predictors: (Constant), X3Total, X2Total, X1Total } \\
\hline
\end{tabular}

Source: Data processed by researchers

In the table above, it is known that the results of the $\mathrm{F}$ test in this study were 33.671 with a significance value of 0.000 which was less than 0.05 , so it can be concluded that the independent variables are service quality $\left(\mathrm{X}_{1}\right)$, price $\left(\mathrm{X}_{2}\right)$, and word of mouth $\left(\mathrm{X}_{3}\right)$ has a significant simultaneous effect on the dependent variable, namely purchasing decisions ( $\mathrm{Y})$. Based on this, the hypothesis $\mathrm{H}_{4}$ is accepted.

\subsubsection{Coefficient of Determination}

Table 4.17. Correlation Coefficient $(\mathbf{R})$ and Coefficient of Determination $\left(\mathrm{R}^{2}\right)$

\begin{tabular}{|c|c|}
\hline $\begin{array}{c}\text { Coefficient } \\
\text { Correlation }(\mathbf{R})\end{array}$ & $\begin{array}{c}\text { Coefficient } \\
\text { Determination }\left(\mathbf{R}^{2}\right) \\
\end{array}$ \\
\hline 0,888 & 0,789 \\
\hline
\end{tabular}

Based on Table 4:17, the coefficient of determination $\left(\mathrm{R}^{2}\right)$ in this study amounted to 0.789 which indicates that the variable quality of service $\left(\mathrm{X}_{1}\right)$, price $\left(\mathrm{X}_{2}\right)$ and word of mouth $\left(\mathrm{X}_{3}\right)$ influence purchasing decisions feeder PT Daniel Ocean Abadi is $78.9 \%$, while the remaining $21.1 \%$ is influenced by other variables not included in this study.

\section{Conclusions and Practical Implication}

\subsection{Conclusion}

Based on the results of research and discussions that have been carried out previously, it can be concluded that the service quality variable $\left(\mathrm{X}_{1}\right)$ partially has a positive and significant effect on the purchase decision of PT Daniel Samudra Abadi's loading and unloading services. So that the first hypothesis that service quality has a significant effect on purchasing decisions for loading and unloading services at PT Daniel Samudra Abadi is acceptable.

The price variable $\left(\mathrm{X}_{2}\right)$ partially has a positive and significant effect on the purchase decision of PT Daniel Samudra Abadi's loading and unloading services. So that the second hypothesis that the price has a significant effect on the purchase decision of PT Daniel Samudra Abadi's loading and unloading services can be accepted.

The word of mouth variable $\left(\mathrm{X}_{3}\right)$ partially has a positive and significant effect on the purchasing decisions of PT Daniel Samudra Abadi's loading and unloading services. So that the third hypothesis that word of mouth has a significant effect on purchasing decisions for loading and unloading services at PT Daniel Samudra Abadi is acceptable.

The variables of service quality $\left(X_{1}\right)$, price $\left(X_{2}\right)$, and word of mouth $\left(X_{3}\right)$ simultaneously have a positive and significant effect on the purchasing decisions of PT Daniel Samudra Abadi's loading and unloading services. So the fourth hypothesis that service quality, price and word of mouth simultaneously have a significant effect on purchasing decisions for loading and unloading services at PT Daniel Samudra Abadi can be accepted.

\subsection{Practical Implication}

Table 5.1. Managerial Implications of Service Quality Variables $\left(X_{1}\right)$

\begin{tabular}{|l|l|l|}
\hline \multicolumn{1}{|c|}{ Indicator } & \multicolumn{1}{c|}{ Before Research } & \multicolumn{1}{c|}{ After Research } \\
\hline $\begin{array}{l}\text { PT Daniel Samudra Abadi has } \\
\text { adequate and modern } \\
\text { company facilities }\end{array}$ & $\begin{array}{l}\text { Some tools for the loading and } \\
\text { unloading process are still using } \\
\text { the old year (obsolete) }\end{array}$ & $\begin{array}{l}\text { Checking loading and unloading aids } \\
\text { regularly and updating loading and } \\
\text { unloading aids such as worn slings or } \\
\text { spreaders }\end{array}$ \\
\hline $\begin{array}{l}\text { PT Daniel Samudra Abadi } \\
\text { provides fast loading and } \\
\text { unloading services as } \\
\text { promised }\end{array}$ & $\begin{array}{l}\text { The quality of loading and } \\
\text { unloading services provided by PT } \\
\text { Daniel Samudra Abadi is good, } \\
\text { but still needs improvement }\end{array}$ & $\begin{array}{l}\text { Routinely conduct briefings before the } \\
\text { operational process, so that employees can } \\
\text { work optimally quickly and precisely as } \\
\text { promised to customers }\end{array}$ \\
\hline
\end{tabular}




\begin{tabular}{|l|l|l|}
\hline $\begin{array}{l}\text { PT Daniel Samudra Abadi is } \\
\text { responsive to every problem } \\
\text { faced by customers }\end{array}$ & $\begin{array}{l}\text { The loading and unloading report } \\
\text { is only done when the loading and } \\
\text { unloading process is complete }\end{array}$ & $\begin{array}{l}\text { Gave a report to the consignee during the } \\
\text { unloading process took place (from start to } \\
\text { end) in the form of pictures and documents, } \\
\text { through whatsapp and email }\end{array}$ \\
\hline $\begin{array}{l}\text { PT Daniel Samudra Abadi } \\
\text { provides guarantee insurance } \\
\text { during the operational process }\end{array}$ & $\begin{array}{l}\text { PT Daniel Samudra Abadi always } \\
\text { provides guarantee insurance } \\
\text { during the operational process }\end{array}$ & $\begin{array}{l}\text { Guarantee the provision of insurance to } \\
\text { the consignee in the event of an accident, so } \\
\text { that the consignee is satisfied }\end{array}$ \\
\hline $\begin{array}{l}\text { PT Daniel Samudra Abadi } \\
\text { maintains good relationship } \\
\text { with customers }\end{array}$ & $\begin{array}{l}\text { PT Daniel Samudra Abadi } \\
\text { entertained } \\
\text { several consignees who had long- } \\
\text { term cooperation }\end{array}$ & $\begin{array}{l}\text { PT Daniel Samudra Abadi will entertain } \\
\text { all consignees in order to maintain good } \\
\text { relations, and maintain consignee's trust }\end{array}$ \\
\hline
\end{tabular}

Source: Data processed by researchers

Table 5.2. Managerial Implications of Price Variables $\left(X_{2}\right)$

\begin{tabular}{|l|l|l|}
\hline \multicolumn{1}{|c|}{ Indicator } & \multicolumn{1}{|c|}{ Before Research } & \multicolumn{1}{c|}{ After Research } \\
\hline $\begin{array}{l}\text { Affordable prices for loading } \\
\text { and unloading services are a } \\
\text { consideration for using the } \\
\text { services of PT Daniel } \\
\text { Samudra Abadi }\end{array}$ & $\begin{array}{l}\text { Pricing is the main focus of the } \\
\text { company }\end{array}$ & $\begin{array}{l}\text { The company's focus is not only on pricing } \\
\text { but also on the quality of loading and } \\
\text { unloading services provided to consumers }\end{array}$ \\
\hline $\begin{array}{l}\text { The price of the service is in } \\
\text { accordance with the quality of } \\
\text { loading and unloading } \\
\text { services offered by PT Daniel } \\
\text { Samudra Abadi }\end{array}$ & $\begin{array}{l}\text { The quality of service and prices } \\
\text { provided to consumers are quite } \\
\text { appropriate }\end{array}$ & $\begin{array}{l}\text { Reviewing the suitability of prices with the } \\
\text { quality of services provided to consumers }\end{array}$ \\
\hline $\begin{array}{l}\text { The service price is in } \\
\text { accordance with the benefits } \\
\text { of loading and unloading } \\
\text { services offered by PT Daniel } \\
\text { Samudra Abadi }\end{array}$ & $\begin{array}{l}\text { The company has complete } \\
\text { services but does not have a } \\
\text { service package price }\end{array}$ & $\begin{array}{l}\text { Providing service package prices, not only } \\
\text { loading and unloading, but } \\
\text { also EMKL trucking services, and surveyors }\end{array}$ \\
\hline $\begin{array}{l}\text { The price of services offered } \\
\text { by PT Daniel Samudra Abadi } \\
\text { is quite competitive }\end{array}$ & $\begin{array}{l}\text { The price of PT Daniel Samudra } \\
\text { Abadi's loading and unloading } \\
\text { services is still above the } \\
\text { competitor's price range }\end{array}$ & $\begin{array}{l}\text { Improve and maintain the quality of loading } \\
\text { and unloading services }\end{array}$ \\
\hline
\end{tabular}

Source: Data processed by researchers

Table 5.3. Managerial Implications of Word of Mouth Variables $\left(X_{3}\right)$

\begin{tabular}{|l|l|l|}
\hline \multicolumn{1}{|c|}{ Indicator } & \multicolumn{1}{c|}{ Before Research } & \multicolumn{1}{c|}{ After Research } \\
\hline $\begin{array}{l}\text { I have heard a lot of positive } \\
\text { things about the quality of PT } \\
\begin{array}{l}\text { Daniel Samudra Abadi's } \\
\text { loading and unloading services } \\
\text { from other people }\end{array}\end{array}$ & $\begin{array}{l}\text { PT Daniel Samudra } \\
\text { Abadi's branding is good }\end{array}$ & $\begin{array}{l}\text { Maintaining the company's branding by } \\
\text { maintaining the company's work } \\
\text { performance }\end{array}$ \\
\hline $\begin{array}{l}\text { I got a recommendation for PT } \\
\text { loaniel Samudra Abadi's } \\
\text { from other people }\end{array}$ & $\begin{array}{l}\text { Collaborating with shipping } \\
\text { companies }\end{array}$ & $\begin{array}{l}\text { Maintain good relationship with shipping } \\
\text { company, increase shipping } \\
\text { company relationship, and also maintain } \\
\text { good relationship with consignee directly }\end{array}$ \\
\hline $\begin{array}{l}\text { I got encouragement from my } \\
\text { relations to purchase the } \\
\text { loading and unloading services } \\
\text { of PT Daniel Samudra Abadi }\end{array}$ & $\begin{array}{l}\text { PT Daniel Samudra Abadi relies } \\
\text { on word of mouth to reach the } \\
\text { market }\end{array}$ & $\begin{array}{l}\text { In addition to word of mouth, PT Daniel } \\
\text { Samudra Abadi needs to provide websites } \\
\text { and corporate social media platforms such } \\
\text { as websites and Facebook to expand market } \\
\text { reach }\end{array}$ \\
\hline
\end{tabular}

Source: Data processed by researchers

\section{References}

Dea, R., \& Anti, F. (2019). Analisis pengaruh harga, citra perusahaan dan kualitas pelayanan terhadap kepuasan pelanggan pada jasa pengiriman kargo di PT. Serasi Shipping Indonesia cabang Semarang. Universitas Maritim Amni.

Fadil, Z., \& Priyo, U. (2015). Teknik marketing itu mudah (Perencanaan marketing strategis untuk mengurus bisnis). Yogyakarta: Second Hope.

Farli, F., \& Tielung, M. V. J. (2015). Pengaruh citra merek, kualitas layanan dan lokasi terhadap keputusan konsumen menggunakan jasa Salon Headquarters Manado Town Square. Jurnal EMBA: Jurnal Riset Ekonomi, Manajemen, Bisnis Dan Akuntansi, 3(1), 1106-1116. https://doi.org/10.35794/emba.v3i1.7925

Hasan, A. (2013). Marketing dan kasus-kasus pilihan. Yogyakarta: CAPS (Center For Academic Publishing Service). 
Hidayat, D. R., \& Firdaus, M. R. (2014). Analisis pengaruh kualitas layanan, harga, kepercayaan, citra perusahaan, dan kepuasan pelanggan terhadap loyalitas pelanggan (Studi pada pelanggan Telkom Speedy di Palangka Raya). Jurnal Wawasan Manajemen, 2(3). https://doi.org/http://dx.doi.org/10.20527/jwm.v2i3.16

Jimanto, R. B. (2014). Pengaruh service quality terhadap loyalitas pelanggan dengan customer satisfaction sebagai variabel intervening pada itrel bioskop the premier Surabaya. Jurnal Strategi Pemasaran, 2(1), 1-7.

Kasmir. (2017). Customer service excellent: Teori dan praktek. Jakarta: Rajagrafindo Persada.

Kaura, V., Durga Prasad, C. S., \& Sharma, S. (2015). Service quality, service convenience, price and fairness, customer loyalty, and the mediating role of customer satisfaction. International Journal of Bank Marketing, 33(4), 404-422. https://doi.org/10.1108/IJBM-04-2014-0048

Kotler, P., \& Keller, K. L. (2012). Marketing management (14th ed.). New Jersey: Prentice Hall.

Kotler, P., \& Keller, K. L. (2016). Marketing management (15th ed.). New Jersey : Pearson Education South Asia PTe Ltd.

Sernovitz, A., \& Kawaskaki, G. (2015). Word of mouth marketing: How smart companies get people talking. UK: PressBox Publishing. https://books.google.co.id/books?id=VnUjrgEACAAJ

Setyo, P. E. (2017). Pengaruh kualitas produk dan harga terhadap kepuasan konsumen best autoworks. Jurnal Manajemen Dan Start-Up Bisnis, 1(6), 755-764.

Sugiyono. (2016). Memahami penelitian kualitatif. Bandung: Alfabeta.

Sugiyono. (2018). Metode penelitian kuantitatif, kualitatif, dan R\&D. Bandung: Alfabeta.

Sugiyono, S. (2017). Metode penelitian kuantitatif, kualitatif, dan R\&D. Bandung: Alfabeta.

Sujarweni, V. W. (2016). Metode penelitian: Lengkap, praktis, dan mudah Dipahami. Yogyakarta: Pustaka Baru Press.

Sujarweni, V Waratna. (2016). Kupas tuntas penelitian akuntansi dengan SPSS. Yogyakarta: Pustaka Baru Press.

Sulayman, M. M., Ernawati, E., \& Indarini, I. (2013). Pengaruh dimensi service quality terhadap customer satisfaction serta pengaruh customer satisfaction dan trust terhadap customer loyalty BCA di Surabaya. Calyptra: Jurnal Ilmiah Mahasiswa Universitas Surabaya, 1(1), 1-23.

Sunyoto, D. (2012). Analisis Validitas dan Asumsi Klasik. Yogyakarta, Gava Media.

Sutanto, J. E. (2010). Analisis keinginan konsumen terhadap keputusan membeli produk. Jurnal Bisnis Indonesia, $1(2), 1-11$.

Tjiptono, F. (2015). Strategi pemasaran (Edisi 4). Jakarta: Andi. 